\title{
NORTHERN IRELAND'S 1968 AT THE ULSTER MUSEUM
}

Chris Reynolds

School of Arts and Humanities Nottingham Trent University

Clifton lane

Nottingham NG11 8NS

United Kingdom chris.reynolds@ntu.ac.uk

\begin{abstract}
In the dominant and increasingly prevalent transnational narrative of 1968 , the case of Northern Ireland has been marginalised. As well as explaining how such an erroneous absence is to be understood, this article, through the example of an ongoing project at Belfast's Ulster Museum, will argue that the current post-Troubles context provides fertile terrain for a recalibration of how this period is remembered from both within and without. It is concluded that such a project offers potentially valuable lessons for handling the difficult question of the past in Northern Ireland and beyond.
\end{abstract}

Keywords: 1968, Northern Ireland, Troubles, memory, museums.

\section{Introduction}

2018 marks the $50^{\text {th }}$ anniversary of the global events of 1968 and the accompanying commemorative focus has seen further progression and consolidation of the narrative that posits 1968 as a year of transnational revolt and rebellion. This article takes for its focus the case of Northern Ireland's 1968 and how its place in the ever-strengthening and expanding transnational narrative has been undergoing significant change in recent years. After outlining how the consensual transnational narrative has been forged, there then follows a discussion into how and why Northern Ireland has been so often marginalised from the collective memory of this period. The article will then conclude with how the onset of peace in the troubled province has opened up possibilities to recalibrate the memory of Northern Ireland's 1968 and in particular how an ongoing project at Belfast's Ulster Museum is reflecting and feeding into this process and what lessons can be learnt as a result.

\section{The Transnational Revolt of 1968}

The term '1968' does not just indicate a specific calendar year. In fact, these four digits have become synonymous with one of the most intriguing periods in recent history and one that has been the focus of much media, public and 
academic attention. There are many potential explanations for such interest in this period. For example, a certain nostalgia for better, safer, surer times is not difficult to understand. Who today would not long for the economic growth that dominated at this time, with unemployment virtually non-existent? Who today would not long for the political stability that reigned in the years that followed the Second World war? Who today would not wish for the depth of innovative, creative and inspiring cultural expression that has become so intrinsically linked to the 1960s? Overall, from the perspective of 2018, there is little difficulty in understanding why '1968' appears to be such an attractive era. However, another potential explanation for the borderline fascination with this 'year' is the,

increasingly consensual, interpretation of it as a period of transnational revolt. From today's viewpoint, it is almost a given that in order to truly make sense of this period, one must look at it from a transnational perspective. To some extent, this is nothing new; even at the time, an awareness amongst those actively involved of what was happening elsewhere in the world was an important element in understanding how and why they were involved in their own domestic revolts. However, such recognition has been on a journey as the commonalities that strengthen the interpretation of it as a period of transnational revolt have become progressively evident as the years have passed. ${ }^{1}$ Such developments have consolidated the notion of a shared revolt and permitted a widening of the geographical optic. Whereas the early stages of the European perspective very much focussed on the areas in the North and West (such as France and Germany), as time passed, more and more experiences of 1968 have become part of the discussion. ${ }^{2}$ For example, as the dictatorships of Southern Europe collapsed, the stories of Greece and Spain began to be stitched into the transnational narrative. ${ }^{3}$ The collapse of communism following the 'fall of the wall' in 1989 led to Eastern Europe starting to carve out its place in the 1968 story with experiences in countries such as Hungary and Poland recounted through the prism of '68'. If we look beyond Europe and consider the global context, the previous dominance of events in the USA or China are increasingly challenged by what could be described as 'peripheral' or 'difficult' 1968s. This includes, for example, events in Africa, Mexico, Iceland and, as we will see later, Northern Ireland. ${ }^{5}$

The fact that so many revolts took place at more or less the same time is almost enough on its own to make a case that there is indeed something exceptional about this period. It cannot have been a coincidence that such widespread revolt all over the world took place during the same, relatively brief, lapse of time. This is particularly true when one considers some of the striking crossover in other areas. Whether it is in terms of the make-up of those involved, their forms of action, their common influences and inspirations, the language used, the strong contextual similarities, the convergent demands or their shared cultural references, it is without doubt the case that something quite exceptional brought this multitude of revolts together, lending weight to the argument that we are dealing, not with individual national revolts but in fact, something much more interesting. ${ }^{6}$ It is perhaps the drive to make sense of what lay behind such strong transnational commonalities that helps explain the huge interest shown in this period of recent history.

1 David Caute, Sixty-Eight. The Year of the Barricades; A Journey through 1968, Harper and Row, 1988; Ronald Fraser, 1968: a student generation in revolt, Pantheon, 1988; Frederic Jameson, 'Periodizing the 60s'. Social Text, No. 9/10, Spring Summer, 1984, 178-209; George Katsiaficas, The Imagination of the New Left: A Global Analysis of 1968, South End Press, 1987.

2 Robert Gildea, James Mark, and Anette Warring, Europe's 1968. Voices of revolt, Oxford University Press, $2013,326-338$.

3 C.f. for example, Polymeris Voglis, 'The Junta Came to Power by the Force of Arms, and Will Only Go by Force of Arms', Cultural and Social History, 8:4, 2011, 551-568; Rebecca Clifford \& Nigel Townson, 'The Church in Crisis, Cultural and Social History, 8:4,2011, 531-550.

4 C.f. for example, James Mark and Piotr Apor, 'Mobilizing Generation: The Idea of 1968 in Hungary', in von der Goltz A (eds) Talkin' 'bout my generation. Conflicts of Generation Building and Europe’s 1968, Wallstein Verlag, 2011, 99-118; Juliane Fürst, Piotr Osęka \& Chris Reynolds 'Breaking the Walls of Privacy', Cultural and Social History, 8:4, 2011, 493-512.

5 C.f. for example, Susan Draper, 1968 Mexico: Constellations of Freedom and Democracy, Duke Univeristy Press, 2018; Chris Reynolds, Sous les pavés...the Troubles. Northern Ireland, France and the European Collective memory of 1968, Peter Lang, 2015; George Katsiaficas, Kathleen Cleaver, Carlos Munoz, The Global Imagination of 1968: Revolution and Counterrevolution, PM Press, 2018; Andy Stafford, 'Senegal: May 1968, Africa's Revolt' in Philipp Gassert and Martin Klimke, 1968. Memories and Legacies of a Global Revolt, German Historical Institute, 2009.

6 Norbert Frei, 1968. Jugendrevolte und globaler Protest, Deutscher Taschenbuch Verlag, 2008; Philippe Gassert, and Martin Klimke, eds, 1968 - Memories and Legacies of a Global Revolt, German Historical Institute, 2009; Robert Gildea, James Mark, and Anette Warring, Europe's 1968. Voices of revolt, Oxford University Press, 2013; Vladimir Tismaneanu, ed, Promises of 1968: Crisis, Illusion and Utopia, Central European Press, 2011; von der Goltz, 'Talkin’ ‘bout my Generation’: Conflicts of Generation Building and Europe’s $1968,2011$. 
In the years immediately following 1968 the focus was principally national as countries grappled with taking on board what they had experienced, what caused it and what the potential consequences and lessons would be. However, before long, a process began that would see the shift towards a transnational focus become progressively more prominent. This process arguably came to a head on the $40^{\text {th }}$ anniversary of the 1968 events when there was a surge in studies that took on and interrogated the transnational nature of the 'year' of revolt. ${ }^{7}$ By this point, consensus had emerged that an understanding of any national '1968' was predicated on placing it within the rather exceptional international context of the time. Ever since 2008, studies have continued to emerge to further consolidate and anchor this reading and, more recently, as indicated above, there has even been an increase in interest around '1968s' that have been typically marginalised in the dominant narrative. ${ }^{8}$ This international flavour has continued to be a major feature of '1968 studies', figuring strongly in the $50^{\text {th }}$ anniversary commemorative period.

\section{Northern Ireland's Forgotten '68"}

Whilst the understanding of 1968's transnationalism has been consolidated over the years and the roster of those having experienced a '1968' has expanded exponentially, it has been interesting to note the persistent absence of one particular set of events. When one considers the plethora of material focussed on examining the transnational aspect of this 'year' of revolt, it is clear that Northern Ireland and its '68' is largely absent. ${ }^{9}$ In fact, in the transnational collective memory of this period, Northern Ireland has been marginalised, forgotten even. One could be forgiven for assuming that nothing of any significance happened in Northern Ireland at this time, thus explaining why it is not mentioned in the same breath as those nations that have come to define the period. Alternatively, one could also assume that if something did occur, it was so very different that no case can be made for it to be thought of in the same light as events in Rome, Paris or Berlin for example. However, this is not the case. Anyone with a minimal understanding of Northern Irish history will know that 1968 was a pivotal year in determining the (unfortunately terrible) sequence of events that would follow and go on to define the troubled province. It is a widely held view that the conflict known as the 'Troubles' started in the aftermath of Northern Ireland's 1968. As communal tensions mounted in the six months following February 1969, the government was eventually forced to call for assistance from the British Army. Such a decision only served to fan the flames of sectarian division and culminated in the tragic events of 'Bloody Sunday' in 1972. The 'Troubles' would rage until 1998 with over 3,600 people losing their lives. ${ }^{10}$ Therefore, the argument that nothing happened simply does not stand-up; and nor does the notion of Northern Ireland as a case apart.

As has been analysed and argued in some detail elsewhere, ${ }^{11}$ there is an extremely strong case for Northern Ireland to be included in the ever-growing list of those having experienced a '1968' and thus considered part of the transnational narrative. On 5 October 1968, a peaceful, but banned, civil rights protest was brutally repressed by local police on the Derry/Londonderry's Duke street. The local, national and international revulsion at the television images

7 Cathy Crane and Nicholas Muellner, (1968) Episodes of Culture in Contest, Cambridge Scholar Publishing, 2008; Gerard de Groot, The Sixties Unplugged, Pan Books, 2008; Egil Førland, 'Special issue on 1968', Scandanavian Journal of History, 33, 4, 2008.

8 Patrick Dramé and Jean Lamarre, eds, 1968. Des sociétés en crise: une perspective globale/Societies in crisis: A global perspective, Les Presses de I'Université de Laval, 2009; Nora Farik, 1968 Revisited. 40 years of protest movements, Heinrich Boll Foundation, 2008; Gildea, Mark and Warring, Europe's 1968. Voices of revolt; Martin Klimke and Joachim Scharloth, 1968 in Europe. A History of Protest and Activism, Palgrave Macmillan, 2008; Michelle Zancarini-Fournel, Les luttes et les rêves. Une histoire populaire de la France. De 1685 à nos jours, Zones, 2016, pp. 778-865.

9 For example, see Ingo Cornilis and Sarah Waters, eds, Memories of 1968. International perspectives, Peter Lang, 2010; Geneviève DreyfusArmand, Les Années 68. Un monde en mouvement. Nouveaux regards sur une histoire plurielle, Syllepse, 2008; Carole Fink, Philipp Gassert, and Detlef Junker, eds, 1968: The World Transformed, Cambridge University Press, 1998; Caute, Sixty-Eight. The Year of the Barricades; A Journey through 1968.

10 A whole plethora of academic research in Northern Ireland's Troubles exists. Some useful starting points include Thomas Hennessey, $A$ History of Northern Ireland. 1920-1996, MacMillan, 1997; David McKittrick and David McVea, Making sense of the Troubles, Penguin, 2001; Henry Patterson, Ireland since 1939, The Persistence of Conflict, Penguin, 2007; Sabine Wichert, Northern Ireland since 1945, Longman, 1991. 11 Reynolds, Sous les pavés...the Troubles. Northern Ireland, France and the European Collective memory of $1968,2015$. 
of these clashes helped swell the ranks of a movement that had been agitating for change around issues of discrimination and inequality from the mid to late 1960s. By mid-November, the government was dealing with a mass movement that included an influential student body known as "People's Democracy" (PD). Despite opposition from within his own ranks, Prime Minister Terence O'Neill decided to offer some concessions to the civil rights movement with the aim of stemming its growth and potential for disruption. However, for some, this was merely a green light to push harder. The PD in particular decided to press ahead with a controversial 'Long March' between Belfast and Derry/Londonderry' that was (almost inevitably) brutally attacked on Burntollet Bridge on 4 January 1969. Such an episode only served to expose and exacerbate the latent inter-communal tensions. O'Neill's response to call for an election in February effectively marked the end of Northern Ireland's 1968 and, as briefly outlined above, would see the beginning of the descent towards the 'Troubles'. ${ }^{12}$

When one closely examines what happened, in terms of the forms of action employed, the make-up of those involved, the language used, the contextual overlap and the awareness of the international circumstances, it becomes obvious that Northern Ireland had its very own '68'. Such commonalities debunk the idea that Northern Ireland was and is a specific case and certainly underscores the argument that what happened there was by no means coincidental but that it was influenced, inspired by, and arguably part of, the wave of protest that was sweeping the globe. Northern Ireland at this time was characterised by what was debatably a specific set of circumstances that would lend weight to the idea that it was a case-apart. The long and difficult history of conflict between Ireland Britain had, by the late 1960s, created a context that was unquestionably specific to Northern Ireland. ${ }^{13}$ In particular, the partition of Ireland since 1921 and the resulting intercommunal tensions in the North around issues of discrimination in the world of work, bias in the provision of social housing and voting inequalities could certainly be cited as contextual considerations that set the province apart. However, the same could be said of any nation that experienced these events, and yet they - unlike Northern Ireland - are included in the transnational narrative. Each manifestation of revolt in 1968 was couched in the local circumstances from which it emanated. Each locality had its own set of priorities, concerns and demands that would define what drove their respective movements. In fact, it is this that lies at the core of making sense of the transnationalism of this period. The exceptional zeitgeist of '1968' was something that provided the grounds for everyone and anyone to voice their concerns and rebel against their status quo. ${ }^{14}$ The commonalities that have allowed the emergence and consolidation of the transnational narrative are not to be understood as suggesting that everyone around the world was asking for the same thing. Instead, it is in the manner with which such demands were made, protests were conducted, inspirations that influenced those involved and the shared, broad contextual circumstances that one finds the glue that has bound these national rebellions together. Northern Ireland unquestionably shared a sufficient number of characteristics to be included in the long list of nations having experienced a '1968' and yet it has been absent from the transnational narrative. How can this be explained? The response lies not in understanding what happened during Northern Ireland's 1968 but instead what happened in its aftermath.

\section{4 'Sous Les Pavés'...the Troubles:15 an Understandable Absence}

Over the course of the last five decades, as argued above, there has been an emerging narrative on how '1968' should be understood as a time of transnational revolt. Broadly speaking, there has been a consensus around this

\footnotetext{
12 For a more detailed and thorough analysis of this period see, Simon Prince, Northern Ireland's 68. Civil Rights, Global Revolt and the Origins of the Troubles, Irish Academic Press, 2007; Reynolds, Sous les pavés...the Troubles, 2015; Bob Purdie, Politics in the Streets/ The origins of the Civil Rights movement in Northern Ireland, Blackstaff Press, 1990.

13 Chris Reynolds, 'Northern Ireland's 1968 in a Post-Troubles Context', Interventions, 19, 5, $2017,636-37$.

14 Simon Prince, 'Pushing luck too far: '68, Northern Ireland and non-violence,' in Daniel J. Sherman, Ruud van Dijk, Jamine Alinder, A Aneesh, eds, The Long 1968. Revisions and New Perspectives, Indiana University Press, 2017, p. 162; Reynolds, 'Northern Ireland's 1968 in a Post-

Troubles Context', 638.

15 'Sous les pavés...la plage' is arguably the most famous of slogans of many daubed on the walls of Paris during the French events of 1968.
} 
period being considered as a positive turning point. ${ }^{16}$ The dominant interpretation posits this 'year' as a progressive moment when those areas involved broke free from the archaism that had defined their post-war circumstances and took positive strides towards a more modern and liberal future. ${ }^{17}$ This prevailing perspective has in large parts been shaped by the people who were involved in the events at the time. Over the years, and particularly around the commemorative periods, 1968ers have forged a positive narrative that in some cases has even seen the events become the focus of pride and periodic celebration. ${ }^{18}$ This is precisely where the case of Northern Ireland stands out and where the explanation for its absence can be understood.

As briefly discussed above, it was almost immediately following the events of Northern Ireland's 1968 that the Troubles began. This virtual civil war ravaged Northern Ireland and completely defined what happened there during the 1968-98 period. As a result, the post-68 trajectory of Northern Ireland was so different that the memory of its '1968' was set on a completely different course to that of its international counterparts. From without, as the Troubles spiralled out of control, Northern Ireland's place within the emergent positive narrative on these transnational events became difficult to justify. It is therefore hardly surprising that it was left out of the narrative under construction. However, and crucially, it was how Northern Ireland's 1968 was situated in the international context from within that was arguably most significant in the marginalisation of Northern Ireland's 1968. The role of former participants - so important elsewhere - was very different in the Northern Irish context. For example, as the soixanthuitards of France were regaling anyone who would listen with their tales of their own (largely positive) experience, the same cannot be said of those involved in Northern Ireland's 1968. As the Troubles took hold, the situation in Northern Ireland became extremely dangerous. For anyone who had been involved in the events of 1968, they were best advised to keep a low profile and not, like their Parisian colleagues, stake any claim on what had happened. ${ }^{19}$ Furthermore, as the Troubles endured and the death toll rose, there started to emerge a certain degree of regret amongst some elements of those involved who questioned whether or not, given the aftermath, their approach was such a good idea. No-one who participated in Northern Ireland's 1968 set out to trigger the onset of the Troubles. However, the understandable sense of guilt and responsibility that emerged is in such stark contrast to the almost celebratory manner with which these events have been remembered elsewhere that one can fully understand just how and why the story of Northern Ireland's 1968 found itself on the margins.

Northern Ireland had a '1968' and there is a very strong case for the overturn of its erroneous absence from the increasingly prominent transnational narrative of this period. One must understand this absence as a direct consequence of the onset of the Troubles that has meant that, both from without and within, the full story has remained untold and the memory of Northern Ireland's 1968 buried and largely forgotten. Such an absence opens up many interesting questions around the notion of memory construction and is a revealing and potent example of how memories, national or transnational, are not set in stone. This is particularly true when one considers how things are changing as Northern Ireland has moved into an era of peace.

\section{The Times They Are A-Changin - the Post-Troubles Context}

The Good Friday Agreement ${ }^{20}$ marked the beginning of what could tentatively be described as an era of peace in Northern Ireland. Whilst this date marked the end of the Troubles and the beginning of an ongoing and very difficult

16 Gildea, Mark,and Anette Warring, Europe's 1968. Voices of revolt, 2013, 336-38.

17 Reynolds, Sous les pavés...the Troubles, 2015.

18 Jean-Pierre Rioux, 'L'événement-mémoire. Quarante ans de commémorations', Le Débat 149, March-April, $2008,49-58$.

19 Reynolds, Sous les pavés...the Troubles. Northern Ireland, France and the European Collective memory of 1968, $2015,172-76$.

20 Peace accord signed on 10 April 1998 by the British and Irish governments as well as all major NI political parties. This agreement effectively signalled the end of the 'Troubles' by setting out a new way forward for governing Northern Ireland. 
peace process, it would be incorrect to say that the problems of the troubled province are at an end. There have been, over the last 20 years, many difficulties and challenges that have rendered the road to peace very difficult. ${ }^{21}$ However, despite such problems, Northern Ireland is today in a very different place than it was during the era of the Troubles. One cannot help but note the widespread change that has been an undeniable consequence of the conclusion of the Troubles. Such change has opened up opportunities for Northern Ireland across the board, possibilities that, during the years of violence, would simply have been unthinkable. As well as the quite obvious reduction in the once daily acts of violence, one only has to look at the investment in infrastructure, the surge in tourism or the positivity surrounding recent sporting achievements as examples of how times have indeed changed. ${ }^{22}$ Such opportunities are also becoming available in one of the most challenging and critically important elements of the peace-building process.

As the peace-process has bedded in and Northern Ireland has become accustomed to the post-Troubles context, one issue in particular has risen to prominence as an area that has the potential to problematise the normalisation of Northern Irish society. Dealing with the difficult legacy of Northern Ireland's past is fraught with issues and, as recent tensions have underscored, it is generally accepted that if the province is to progress into a positive future, this can only really be achieved by meeting the challenges of its contested past. Such is the significance of this issue, that local politicians as well as the London and Dublin governments have made it one of the top priorities of their ongoing efforts at building sustainable peace..$^{23}$

There can be no doubting the fact that, from a Northern Irish perspective, now is an opportune moment to make such efforts. From a theoretical perspective, it is the case that shifting contexts offer up opportunities to recalibrate memories of past events. It is indeed the overall thesis of Maurice Halbwachs that we construct our memories based on the needs of the present. ${ }^{24}$ As a result, when significant contextual shifts take place, it is only obvious that the possibility to shine new perspectives on past events becomes clear. Such a possibility is enhanced further when one considers the argument of Walkowitz and Knauer who argue that political transformations not only offer the possibility to reconsider the past, but indeed necessitate renewed struggles and encourage the consideration of new and multiple perspectives over important past events..$^{25}$ If one considers the change that Northern Ireland has experienced with the conclusion of the Troubles and the onset of peace, one can easily understand just how the political transformation and contextual shift offers up significant opportunities regarding how the past can and should be handled. The case of Northern Ireland's 1968 is an excellent example of how perspectives on the past are experiencing change.

For the reasons outlined above, during the Troubles, there was little in the way of any effort to commemorate or celebrate Northern Ireland's 1968 in the same way that had become routine in other areas having experienced similar revolts. However, following the onset of peace, an important change was discernible. This became obvious, in particular, during the $40^{\text {th }}$ anniversary of the events in 2008 . For the first time, there was a genuine effort to mark the anniversary of the events in Northern Ireland with a whole plethora of events organised throughout the year. There were a number of important characteristics that indicate just how things had changed. Firstly, in the extensive range of events that took place, it was indeed the former participants that got involved and drove the organisation and delivery of such conferences, study days, film projections and concerts. Secondly, what was once an era defined by silence became, in 2008, the focus of a political struggle as the two prominent Nationalist political parties in Northern Ireland, Sinn Fein and the SDLP, battled with each other over who owned the legacy of this period. Finally, there was genuine attempt in the material produced to couch what happened in

21 Reynolds, 'Northern Ireland's 1968 in a Post-Troubles Context', 641-42.

22 Alan Bairner, 'Still taking sides: sport, leisure and identity', in Colin Coulter and Michael Murray, Northern Ireland after the Troubles?: A Society in Transition, Manchester University Press, 2008, 215-231; Jörg Neuheiser and Stefan Wolff, Peace at Last?: The Impact of the Good Friday Agreement on Northern Ireland, Berghahn, 2004.

23 Michael Potter, 'Dealing with the past in Northern Ireland,' Research Matters, 22 September 2016, https://www.assemblyresearchmatters. org/2016/09/22/dealing-with-the-past-in-northern-ireland/

24 Maurice Halbwachs and Lewis A. Coser, On Collective Memory, University of Chicago Press, 1992 , p. 25.

25 L.M. Knauer and D.J. Walkowitz, eds, Memory and the Impact of Political Transformation in Public Space Duke University Press, 2004, pp.1-18. 
Northern within the international context of the time. ${ }^{26}$ Such a shift must be understood as a direct consequence of the onset of peace. With the shadow of the Troubles lifted, there have been signs of a desire to break out of the insularism that has all too often presented the province as a case apart and immune to international influences and trends. These characteristics that saw the $40^{\text {th }}$ anniversary commemorated with some vigour, with the participants at the forefront and a focus on the international perspective, as well as the fact that it had moved from a period that no-one really spoke of to one that was fought over, indicates just how the conclusion of the Troubles has offered up the possibility for change. Such a reframing of the 1968 events will help recalibrate the memory of this period and importantly permit a consideration of it that is not exclusively channelled through the prism of the conflict. The beginning of a process that will see Northern Ireland's 1968 secure its rightful place in the transnational collective memory of this 'year' of revolt is both a contributing factor and symptom of this change. The $50^{\text {th }}$ anniversary confirms such developments, as is exemplified by my ongoing collaborative project with Belfast's Ulster Museum.

\section{Recalibrating Memories: 1968 at the UIster Museum}

Following the publication of Sous les pavés...The Troubles: Northern Ireland, France and the European Collective Memory of 1968 in 2015, a study that develops in detail the reasons behind the absence of the province's 1968 from the transnational narrative, I made contact with the Ulster Museum in Belfast. There then commenced a fruitful collaboration with the Museum's Director of Collections, William Blair, that would evolve in three distinct stages. The overall objective was to translate the underpinning thesis of my research into museum content with a view to broadening perspectives on how Northern Ireland's 1968 is presented in the permanent gallery of the Ulster Museum. The objective of writing Northern Ireland into the transnational narrative (and vice-versa) met with Blair's broader objective to widen perspectives within the Museum galleries so as to break out from the insularism that has so often defined representations of the past in Northern Ireland, as was evidenced by how the period of 1968 had hitherto been represented in the museum. ${ }^{27}$

Stage one of the process entailed minor adjustments to the existing content with a particular emphasis on subtly introducing some international flavour to the section that was dominated by photos from the period (see Figure 2 below). These minor changes were successful in encouraging visitors to, at the very least, consider that similar events were taking place elsewhere in the world and that there was some sort of influence on what would happen in Northern Ireland.

The success of this first intervention led to the decision to make much more substantial changes to how this period is covered in the permanent gallery. Given the prominence of oral history underpinning the methodological approach of my study, former protagonists' stories were introduced to how this period would be covered. The use of such oral testimonies provides the visitor with an engaging, interactive and immersive experience and crucially, as Thompson argues in his seminal work on this methodological approach, gives a central place to 'the people who made and experienced history, through their own words. ${ }^{28}$ Such an approach, whilst recognised universally as particularly potent, has also been identified as very effective in post-conflict contexts such as that of Northern Ireland ${ }^{29}$ With this in mind, 10 activists, and those well placed to comment, took part in videoed interviews. These interviews were then edited and compiled into sections that relate directly to existing and newly curated objects with a view to providing an interactive and multi-layered experience for the museum visitor (See figures 3 a-c below).

26 Reynolds, Chris, Sous les pavés...the Troubles, pp. 194-201.

27 This new direction in how the Museum is dealing with the recent past is exemplified by the 'Collecting the Troubles and Beyond' project, funded by the UK Heritage and Lottery fund, the success of which is discussed in Patrick Kelly, 'Beyond the Troubles.', Museum Journal, May 2017, 26-29.

28 Paul Thompson, The Voice of the Past: Oral History, Oxford University Press, 1988, 2.

29 'Report on a Workshop held at Hertford College, Oxford, 19 October 2016', Historians and the Stormont House Agreement, http://irish historiansinbritain.org/?p=321 


\section{VIEU}

Chris Reynolds, Northern Ireland's 1968

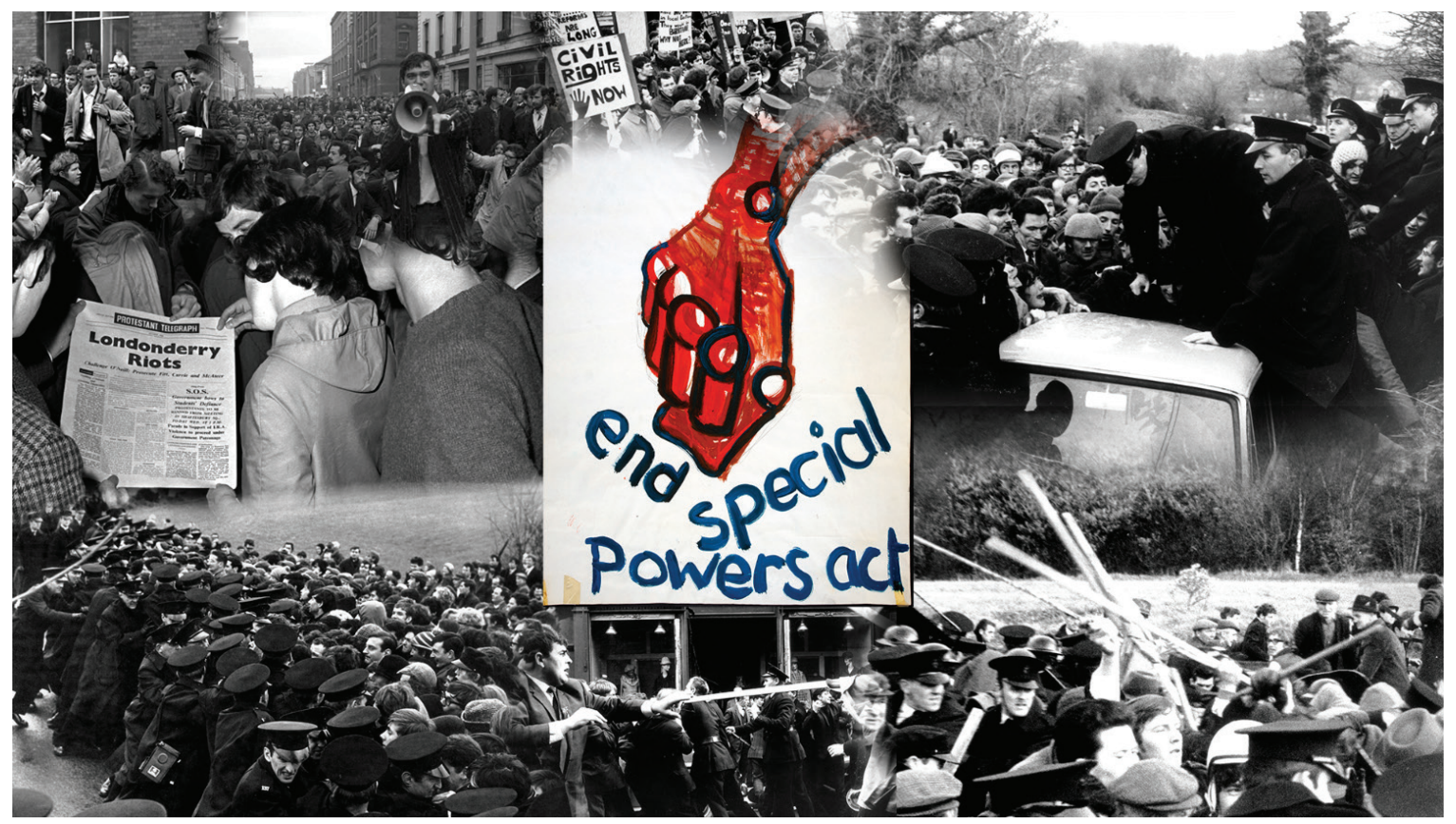

Figure 1. Exhibition title image

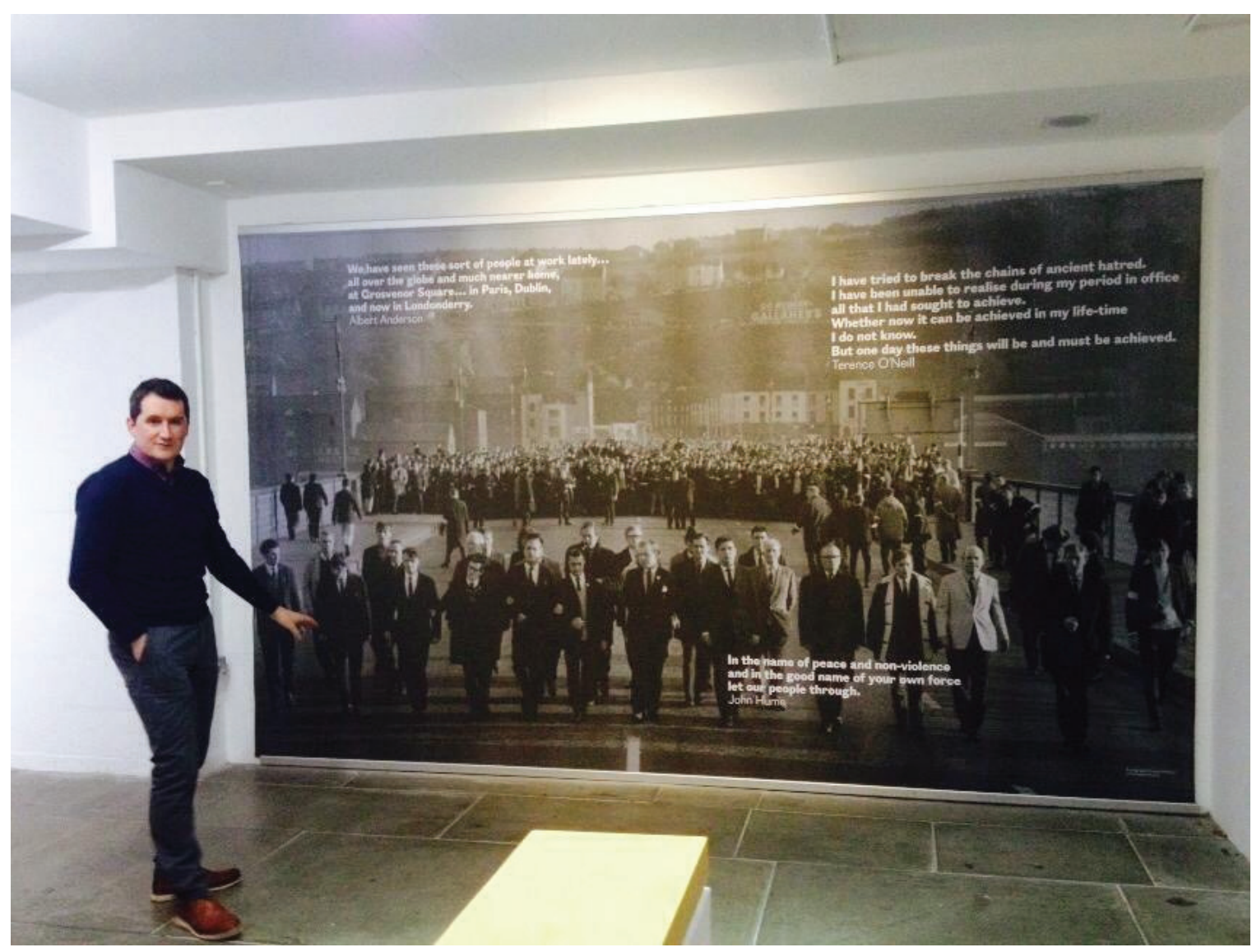

Figure 2. Stage 1: Minor intervention 


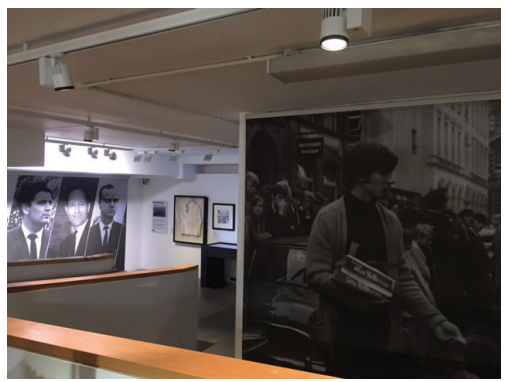

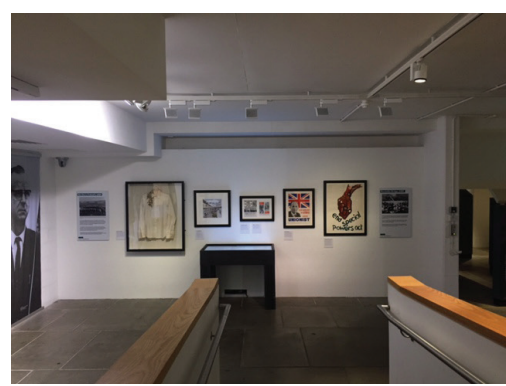

C

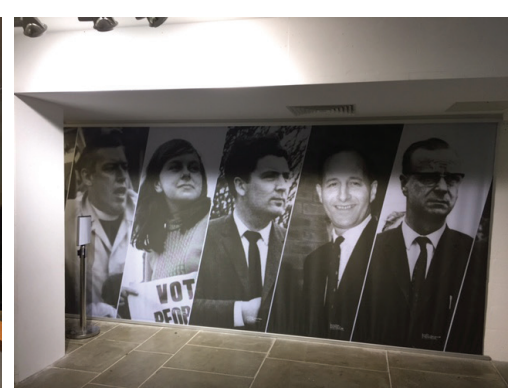

Figures 3 a-c. Stage 2: Substantial redevelopment of permanent gallery

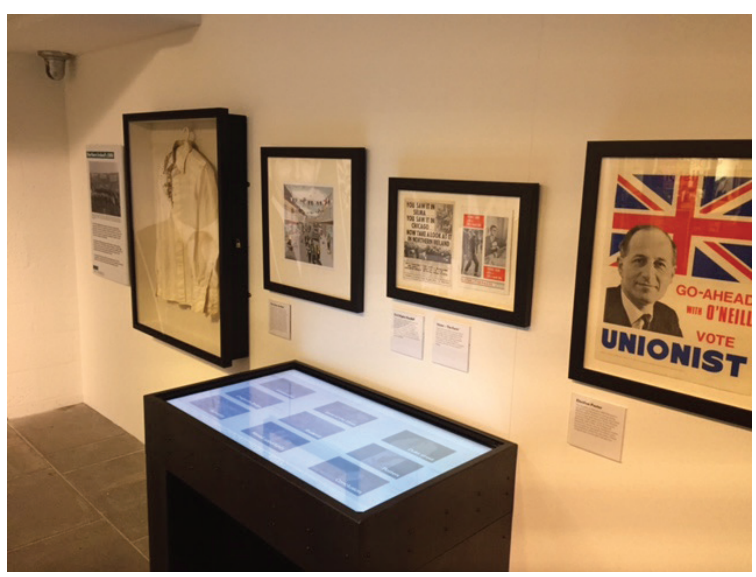

b

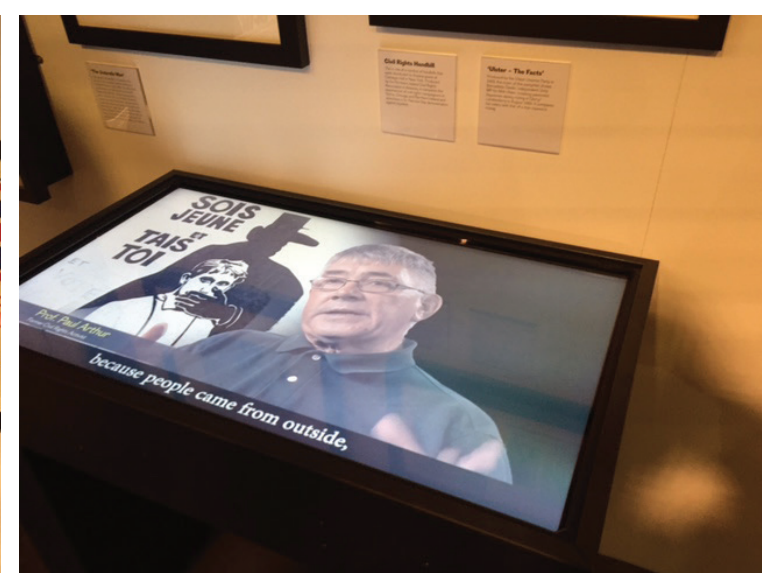

Figures 4 a-b. Stage 2: Interactive touch table - embedded oral history

Specific objects and images were chosen to represent particular plotting points in the chronology of the events. These are used to trigger interviewees' reflections on that precise moment. An interactive touch table now sits in the gallery that enables visitors to hear the context around the objects and images on display as well as testimonies from people having experienced the events in question (See figures $4 \mathrm{a}-\mathrm{b}$ below).

Extended versions of these videos have also been made available via the Museum's YouTube channel so as to offer visitors the opportunity to delve deeper into the extensive interview material available that could not be included in the gallery space.

Another crucial facet of this second stage concerns the involvement of local schools. As the period under investigation is now part of the local history curriculum, a link was established between a number of people involved with teaching and setting the curriculum for history and the Museum with the objective of organising study days (see Figure 5 below). Four of these particular study days have now taken place with pupils from across the communities in Northern Ireland attending the museum for a number of talks from academics and protagonists from the time as well as a guided visit of the galleries.

To complement and enhance the quality of these study days, we entered into a collaboration with the local curriculum body CCEA (Council for the Curriculum, Examinations and Assessment) to develop a set of educational resources specially tailored to the needs of teachers and pupils working on the period of Northern Ireland's 1968. These resources have been made available in hard copy (see figure 6 below) and online and are currently in use in schools across the province. 


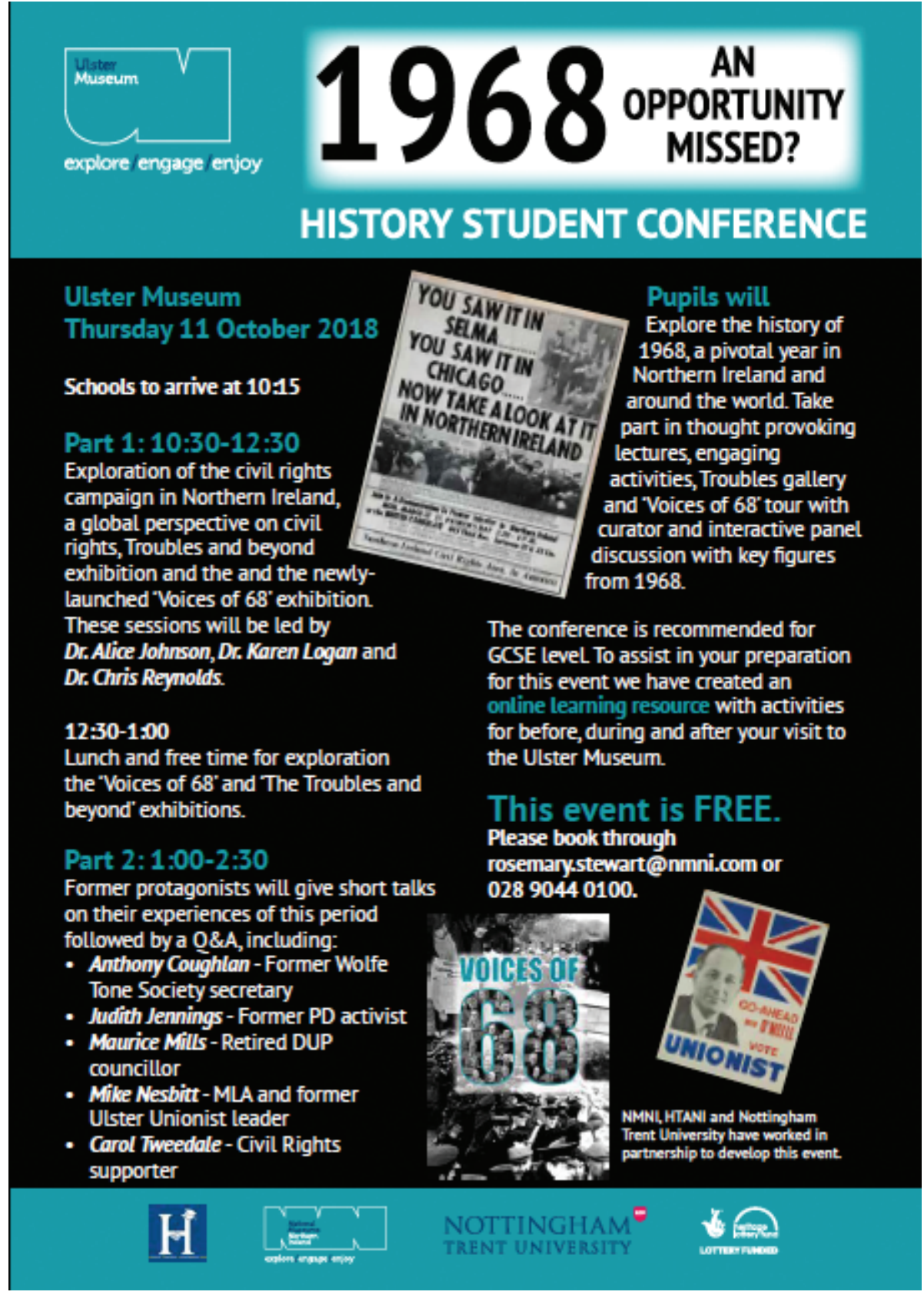

Figure 5. GCSE Study day

Prior to its launch in March 2017, this new section of the permanent gallery and the material within underwent a rigorous evaluation via a number of workshops representing a cross-section of Northern Irish society. The published report of the evaluation process combined with detailed and very rich feedback garnered as part of the study days have offered up insightful perspectives on how generally the past in Northern Ireland remains deeply interesting and is fraught with challenging issues. ${ }^{30}$ For example, it highlighted the ongoing inter-communal divisions surrounding 


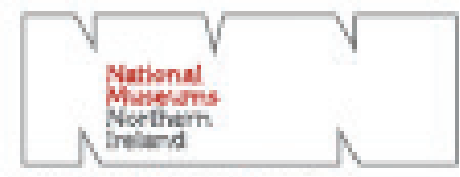

explore fengapeienjoy

\section{Ulster Museum \\ Learning Resource:}

\section{CCEA GCSE History, Section 2, Option B, \\ Changing Re/ations: Northern /reland and its Neighbours, 1965-1998.}

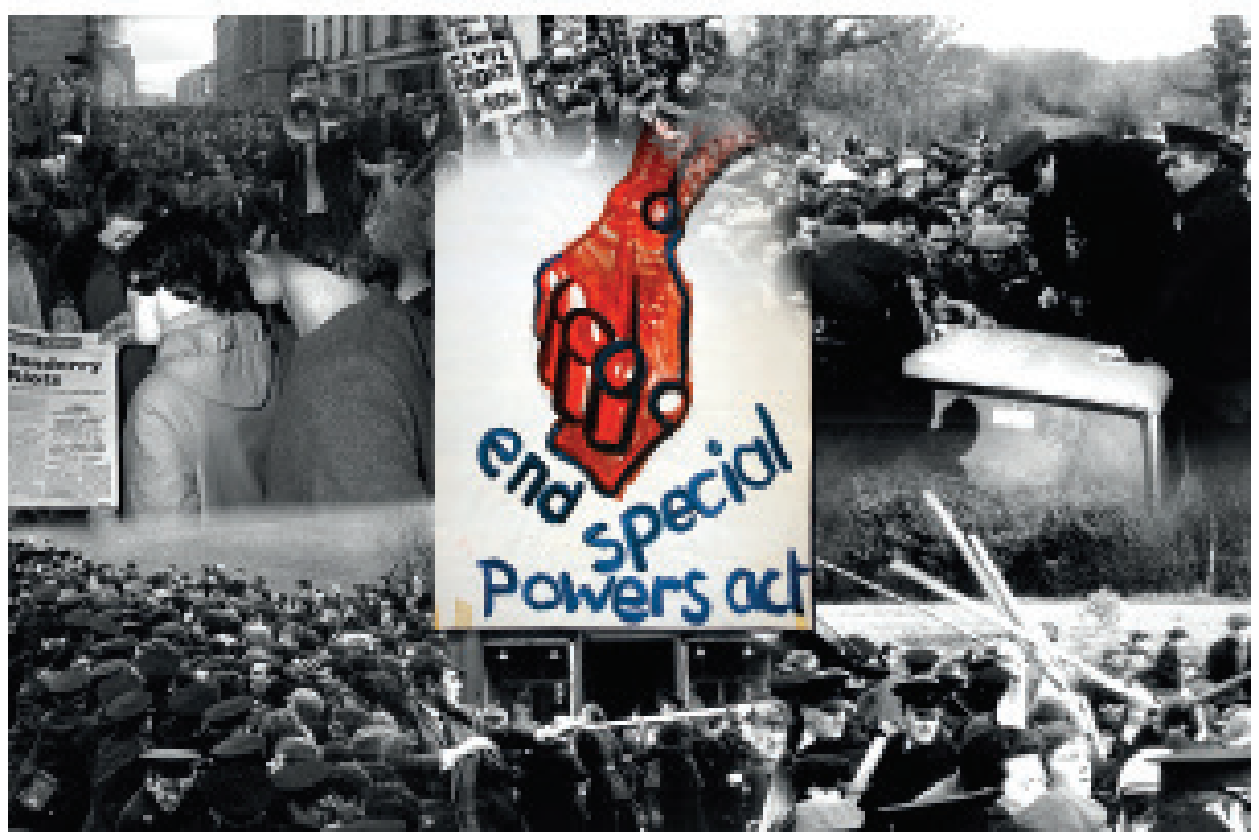

Figure 6. Educational resources

how this period should be remembered and in particular an enduring insularism that persists within one side of the divide in particular. ${ }^{31}$ More specifically, the lessons taken from this process on issues of contextualisation, gender balance and multiperpsectivity have been pivotal in shaping the third and final stage of this project. 
2018 marks the $50^{\text {th }}$ anniversary of the events and in Northern Ireland (like everywhere else) coincided with a significant surge in interest in this period. Building on the progress made on the $40^{\text {th }}$ anniversary, 2018 saw important developments in the way in which the story of this period is told. In particular, the focus on the international context, so crucial to breaking out of the insularism that has defined the construction of the memory of this time, has continued. The Ulster Museum's plans for the $50^{\text {th }}$ anniversary sought to reflect and contribute to such a process. To mark this milestone, the Museum planned a multi-facetted, national programme of events that extended the theoretical and methodological approach employed thus far. A new and expanded, temporary exhibition launched at the Ulster Museum in September 2018 and an accompanying travelling version is to be hosted in over 20 destinations across the UK and Ireland. ${ }^{32}$ A digital version of the exhibition was also developed to enable visitors to extend their study of the material and to facilitate international exposure for the project. ${ }^{33}$ The final aspect of the $50^{\text {th }}$ anniversary project is a three-day event including a GCSE study day, a conference featuring interviewees from the project and a day of reflection on the role of women in 1968 and beyond (see figure 7 below).

It is worth reflecting on why, in such a difficult context, this collaborative project has worked as effectively as it has before concluding on what lessons can be taken from it. There are a number of convergent factors that help us make sense of the success of this project. Firstly, it is an excellent example of how the gap can be bridged between academic research and public-facing institutions with a view to ensuring that such research has an impact in the public domain. There is a whole plethora of excellent academic research on the Troubles that would unquestionably be of great benefit as part of the ongoing peace-process in Northern Ireland. However, typically, such research has struggled to inflect ideas on the ground. ${ }^{34} \mathrm{~A}$ collaboration such as that underpinning this project demonstrates that challenges can be overcome. Secondly, and related, the general distrust of the political elite that has come to define recent times extends to the way in which politicians get involved in telling the public how it should understand the past. This distrust is exacerbated in areas, such as Northern Ireland, where the issue of the past and the divisions it perpetuates is often used by politicians themselves. ${ }^{35} \mathrm{It}$ is precisely here that the encounter between the independent, scholarly research of an academic and the trusted museum sector can create a space that fills the void and which is trusted by the general public to present balanced and inclusive representations of the past. ${ }^{36}$ Such trust is a privileged asset and, in the case of the Ulster Museum's 1968 project, can be evidenced in the enthusiastic involvement and participation of former protagonists, the strong buy-in from the educational sector and the investment of those involved in the evaluation process. One final element to bear in mind concerns the methodological emphasis on oral history. As discussed above, there is strong recognition that such an emphasis on testimonies and storytelling can be a potent and effective approach to building peace and emphasising reconciliation. The centrality of capturing the diverse stories of those having experienced the 1968 events lies at the centre of my research into this period and the approach taken to translate such testimonies into effective museum content goes some way to explaining the success of this project in the Northern Irish context.

In summary then, the multifaceted and ongoing project concerning Northern Ireland's 1968 is an excellent example of how the shifting context that has been the conclusion of the Troubles and the onset of peace has provided a window of opportunity for this period to undergo a certain reconsideration. The potential to open up perspectives with a view

32 The scheduled locations in the UK and Ireland include: Ballymena Library, Derry Central Library: Newry Library: Dungannon Library,

Derry, Guildhall, Belfast City Hall, Ulster University (Magee Campus), Queen's University Belfast, Nottingham Trent University, Irish Cultural

Centre, London Hammersmith, Luton Irish Centre, Victoria Gallery \& Museum, Liverpool, University of Bath, Irish World Heritage Centre,

Manchester, Cardiff University, Cork County Library, Cork City Library, Dublin City Library, Galway, NUIG, Kerry Library, Mayo County Library,

Arklow Library, Tipperary County Library.

33 The digital version is currently scheduled to be on show in San Francisco, Harvard and Florida.

34 Report on a Workshop held at Hertford College, Oxford, 19 October 2016', Historians and the Stormont House Agreement, http://irish historiansinbritain.org/? $p=321$

35 Ibid.

36 Britain Thinks. 'Public Perceptions of - and Attitudes to - the Purposes of Museums in Society,' Museums Association, 2013, https://www. museumsassociation.org/download?id=954916 


\section{ULSTER MUSEIUM}

\section{AND BEYOND}

CONFERENCE PROGRAMME 11-13 OCTOBER

Day 1:

1968 An Opportunity Missed?

10.30-14.30

Morning: school groups will be invited to explore the history of 1968 including the civil rights campaign in Northern Ireland and global perspectives on civil rights.

Afternoon: open to the public, in this session former protagonists will give short talks on their experiences of this period followed by a Q\&A.

Day 2:

Voices of ' 68

10.00-16.00

A total of 30 key protagonists have been interviewed as part of Voices of '68. Day 2 of the conference will involve a range of interviewees from the project reflecting on their experiences of ' 68 and discussing how this period should be remembered.

Speakers to include: Paul Bew, Austin Currie, Anne Devlin, Chris McGimpsey, Bríd Rodgers, Nelson McCausland, Paul Arthur, Henry Patterson.
Day 3:

Women, 1968 and Beyond 10.00-16.00

Part 1: Women in 1968

- Key female protagonists of the time will share their experiences followed by a debate. Speakers to include: Margaret Ward, Brld Ruddy, Bernadette McAliskey.

Part 2: '68

and Beyond

- The focus of this session will be on the ongoing contribution women have made to community activism and peacebuilding since 1968. Speakers to include: Eileen Weir, Kellie Turtle, Bronagh Hinds.

This event is 마를

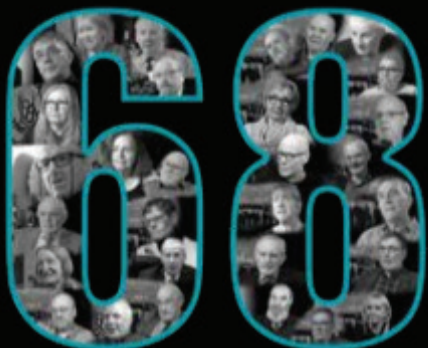

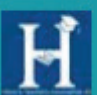

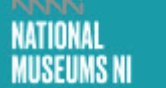


to recalibrating the memory of this period has been amply evidenced through the success of the encounter between academic research and the museum sector. Let me conclude on what lessons can be taken from this project both for within and without.

\section{Conclusion}

The success of the ongoing project concerning the Ulster Museum's treatment of Northern Ireland's 1968 offers up some valuable lessons into how the difficulties of a contested past can be met head on. This is true in terms of the specific Northern Irish context. As mentioned above, there are many challenges associated with dealing with Northern Ireland's all too often divisive past and there is a general consensus that this is a crucial element in the ongoing peace process. The effectiveness of methodological approach outlined above, in combination with the multi-layered focus on public engagement, offers a blueprint that could arguably be employed to deal with other such pivotal moments in the province's recent past. In fact, plans are currently in place to extend the methodology employed in this project to the future, and critically important, development of the Ulster Museum's Troubles gallery. Furthermore, that this collaboration has proved so effective within the very challenging and divisive context of current-day Northern Ireland suggests that such an approach could well be applicable and successful in other areas beyond the borders of Northern Ireland that are also dealing with the legacies of their difficult pasts.

\section{Bi o graph y}

Chris Reynolds is Associate Professor of Contemporary French and European Studies at Nottingham Trent University. His main research interests are in relation to the events of 1968 from a French, Northern Irish and European perspective. In addition to a wide range of articles and chapters on these topics, he is the author of Memories of May'68: France's Convenient Consensus (University of Wales Press, 2011) and Sous les pavés...The Troubles: Northern Ireland, France and the European Collective Memory of 1968 (Peter Lang, 2015). Chris is currently leading a significant project with the Ulster Museum on the question of Northern Ireland's 1968. 